\title{
Islamic Philanthropy and Improving The Quality of Competitive Human Resource : A Lesson from Indonesia
}

\author{
Arin Setiyowati ${ }^{1}$, Irma Muzdalifa ${ }^{2}$, Inayah Aulia Rahma ${ }^{3}$, Fatkur Huda ${ }^{4}$ \\ arin.st@fai.um-surabaya.ac.id ${ }^{1}$,irmamuzdalifa82322@gmail.com² inayaulia7@gmail.com³ \\ huda.fatkur@gmail.com ${ }^{4}$ \\ Universitas Muhammadiyah Surabaya ${ }^{1}$, Universitas Muhammadiyah Surabaya ${ }^{2}$ Universitas \\ Muhammadiyah Surabaya ${ }^{3}$, Universitas Muhammadiyah Surabaya ${ }^{4}$
}

\begin{abstract}
This research focused on the LAZISMU, especially LAZISMU Surabaya strategy in utilizing Islamic Philanthropy in the Education Scholarship program. By using a field research with qualitative- case study approach. Data collection is carried out with in-depth interviews, observations and documentation expected to obtain comprehensive data. Supported by data triangulation as data analysis, so it is expected to obtain valid data with the results that are recomended for reference. The objects of analysis include management of Islamic Philanthropic fund management, education scholarship program policies, guidance, empowerment and human resource development for scholarship recipients to the outputs. So that, throught this research can unravel the significance of Islamic philanthropy in supporting the improvement of the quality of competitive human resources.
\end{abstract}

Keywords: Islamic Philanthropy, LAZISMU, competitive's human resource

\section{Pendahuluan}

Salah satu pilar penting dalam agenda Pembangunan Indonesia adalah Kualitas sumber daya manusia. Global Human Capital Report tahun 2017 melaporkan tentang hasil kajian kualitas SDM di 130 negara dengan beberapa indikator. Salah satu hasilnya menunjukkan bahwa Indonesia berada di urutan ke-65, dibanding tahun sebelumnya naik tujuh peringkat. Sementara negara-negara ASEAN seperti Singapura (11), Malaysia (33), Thailand (40), dan Filipina (50) sudah melesat di atas Indonesia. Sehingga untuk mengejar ketertinggalan kualitas SDM tersebut, Indonesia perlu merumuskan strategi berkelanjutan dalam meningkatkan kualitas SDM. Salah satunya adalah penguatan modal, jika bertumpu pada APBN saja maka tidak cukup.

Di sisi lain, semarak filantropi Islam untuk kepentingan publik telah menarik berbagai sektor dan aktor, mulai negara, organisasi Islam hingga perusahaan dan lembaga pembangunan lainnya yang disesuaikan dengan tujuan masing-masing.[1] Salah satunya ditandai dengan menjamurnya LAZ (Lembaga Amil Zakat) maupun UPZ (Unit Pengumpul Zakat) baik di organisasi Islam kemasyarakatan maupun perusahaan swasta.[2] Adapun kepentingan publik yang menjadi salah satu misi filantripi Islam adalah peningkatan kualitas SDM Indonesia. Sehingga optimalisasi dana filantropi Islam dapat menjadi corner solution melalui kinerja BAZ/LAZ yang produktif, salah satunya melalui LAZISMU (Lembaga Amil Zakat Muhammadiyah). LAZ harus memenuhi klausul sehat, kredibel, efektif, dan efisien jika memenuhi beberapa indikator, meliputi ; pertama, tujuan dan kegiatan lembaga sesuai dengan 
kebutuhan masyarakat. Kedua, program yang dijalankan sejalan dengan misi dan rencana strategis. Ketiga, mengalokasiakan sumber daya yang cukup untuk memastikan bahwa setiap program bisa mencapai sasaran dan tujuannya.[3]

Untuk memotret sejauhmana peranan LAZISMU dalam upaya mendukung peningkatan kualitas sumber daya manusia, khususnya dalam melakukan pendayagunaan dana filantropi Islam dengan program-program kreatif dan produktif untuk umat. Maka penelitian ini dimaksudkan untuk membahas terkait manajemen dana filantropi Islam dalam upaya meningkatkan sumberdaya manusia (SDM) berdaya saing melalui program beastudi pendidikan oleh LAZISM, khususnya LAZISMU Surabaya.

\section{Metode Penelitian}

Penelitian ini menggunakan jenis penelitian lapangan (field research), pendekatan kualitatif deskriptif.[4] Adapun Subyek dan obyek penelitian adalah Lazizmu Surabaya JL.Wuni No.9 Surabaya dengan fokus bahasan tentang analisis filantropi Islam pada sisi pendistribusian dananya pada program beasiswa pendidikan.[5] Sumber data primer diperoleh dari pengurus Lazismu dan beberapa informan mahasiswa penerima biaya studi Lazismu. Pengumpulan data meliputi Observasi, Indepth Wawancara dan Dokumentasi. Pengolahan dan Analisis data dengan triangulasi data. Kemudian dijelaskan secara sistematis berupa kata-kata tertulis dari orang-orang dan data yang diamati.[6] Dari hasil data lapangan berupa fakta-fakta yang bersifat khusus, penulis melakukan penarikan kesimpulan dengan metode induktif. Sehingga dapat ditarik generalisasi yang umum bahwa dana filantropi Islam berperan dalam upaya peningkatan kualitas SDM di Indonesia.

\section{Pembahasan}

Konsep filantropi yang berkembang di Indonesia berperan penting dalam upaya peningkatan kesejahteraan masyarakat miskin, baik secara sosial maupun ekonomi berada di bawah garis kemiskinan. Adapun zakat, infak dan shadaqah dalam Islam merupakan instrumen filantropi Islam yang wajib ditunaikan serta telah menjadi budaya, adat kebiasaan perilaku gotong royong masyarakat.[7]

Filantropi Islam di Indonesia berawal dan berkembang dari wilayah privat, seperti wakaf, infak dan shadaqah hingga saat ini mengarah pada wilayah publik yang terlembagakan secara terstruktur. Hal tersebut menjadikan filantropi Islam di Indonesia tidak sekedar pemberian materi berupa barang atau jasa untuk kepentingan jangka pendek (Charity), namun sudah dikembangkan sebagai kedermawanan yang ditujukan untuk kepentingan jangka panjang yakni masa depan pembangunan Indonesia. Salah satunya meliputi banyaknya program beasiswa pendidikan yang dikucurkan oleh lembaga pengelola zakat, bantuan pendirian sekolah dan sebagainya.[8] Artinya dana filantropi Islam menjadi keniscayaan sebagai instrumen untuk pengembangan pendidikan Indonesia bisa ditopang dari dana filantropi Islam yang dikelola dengan rapi.[9]

Selain mengandung doktrin ibadah, zakat juga memiliki doktrin sosial keagamaan. Dalam Asbabunnuzulnya zakat memiliki dua tahapan, yaitu Makkiyah (bersifat teologis) dan Madaniyyah (Sosial keagamaan). Sebagaimana termaktub dalam Al-Quran meliputi QS. AlLahab: 2-3, QS Al-Humazah: 13, QS At-Taubah: 34, QS Al-Baqaroh: 2-3, 272. Artinya, 
Kehadiran Islam adalah untuk menyelesaikan persoalan sosial ekonomi tanpa terbatas waktu.[12]

Supaya memobilisasi dana filantropi terkelola sistematis, tata kelola zakat Indonesia diatur dalam UU Nomor 38 Tahun 1999. Bahwa terdapat dua organisasi pengelola dana filantropi Islam (zakat, infaq, shodaqoh dsb), yaitu: (1) Badan Amil Zakat (BAZ) merupakan organisasi pengelola zakat yang dibentuk oleh pemerintah, dan (2) Lembaga Amil Zakat (LAZ) merupakan Organisasi pengelola zakat yang diprakarsai oleh swasta yang mendapatkan izin resmi dari pemerintah. Dengan ketentuan bahwa LAZ berkewajiban melaporkan pelaksanaan pengumpulan, pendistribusian dan pendayagunaan zakat yang telah diaudit kesyariahannya maupun kesehatan keuangannya secara berkala kepada BAZNAS. Sehingga posisi LAZ tidak setara dengan BAZ[13].

Hal menarik lain dari semarak filantropi Islam di Indonesia adalah adanya kontestasi antara dua gerakan filantropi Islam (Muhammadiyah dan NU). Pertama, gerakan yang ingin memodernisasi dan menjalankan praktek filantropi secara profesional sebagai bagian dari visi islamisasi masyarakat. Kedua, yaitu gerakan yang tidak ingin keterlibatan aktif negara dalam filantropi Islam ini, yang dipelopori oleh kaum muslim tradisionalis.[1] Terlepas dari kontestasi tersebut, dapat ditarik kesimpulan bahwa filantropi Islam memberikan sumbangsih besar dalam upaya pemberdayaan masyarakat yang kurang mampu dan terpinggirkan oleh derasnya arus globalisasi.

Lembaga pengelola zakat dan dana filantropi Islam yang dikaji dalam penelitian ini adalah Lembaga Amil Zakat Infaq Shadaqah Muhammadiyah (LAZISMU) Surabaya. Salah satu LAZ yang diinisiasi dan dikelola oleh Muhammadiyah, sebagai organisasi Islam terbesar di Indonesia. LAZISMU sebagai lembaga lembaga penghimpun, pendistribusi dan pendayagunaan dana filantropi Islam (zakait, infaq, shodaqoh dan wakaf) untuk menangani persoalan sosial dan ekonomi umat.[10] Dalam hal pendistribusian LAZISMU Surabaya memiliki ragam produk menarik, salah satunya program beasiswa.[14]

- Implementasi Program Beasiswa Pendidikan LAZISMU Surabaya untuk Meningkatkan Kualitas SDM Berdaya Saing

LAZISMU Surabaya memiliki program khusus pendistribusian dana filantropi Islam guna pengembangan pendidikan di daerah Jawa Timur khususnya di kota Surabaya. Program yang dimulai pada tahun 2007 ini menggunakan 25\% dananya guna pengembangan pendidikan. Pengajuan beasiswa Lembaga Amil Zakat Muhammadiyah Surabaya memiliki dua kriteria. Pertama, beasiswa yang bersifat continue atau berkelanjutan dimana dana Pendidikan tersebut dapat dicairkan setiap 3 bulan sekali. Kedua, beasiswa yang bersifat darurat atau insidentil, dana ini dapat diberikan ketika siswa atau penerima beasiswa mengalami tunggakan dalam pembayaran.

Kriteria untuk penerima beasiswa tetap mengedepankan 8 asnaf penerima zakat. Terdiri dari fakir, miskin, amil, mualaf, gharim, hamba sahaya, fi sabilillah dan ibnu sabil. Dana pendidkan ini diperuntukkan bagi pelajar baik dari tingkat sekolah dasar (SD), sekolah menengah pertama (SMP), sekolah menengah atas (SMA) hingga mahasiswa perguruan tinggi berhak mendapatkan bantuan beasiswa dari LAZISMU Surabaya. Pada saat penelitian ini dilaksanakan, terdapat 150 siswa di kota Surabaya yang menerima bantuan beasiswa dari LAZISMU Surabaya. Di antaranya pelajar SD sejumlah 70 siswa, pelajar SMP 48 siswa, SMA 34 siswa dan 8 mahasiswa. Bagi penerima beasiswa mahasiswa, tidak ada uang biaya hidup melainkan hanya beasiswa pendidikan. (Wawancara dengan staf LAZISMU Surabaya tanggal 22 Februari 2019)

Dalam program ini LAZISMU Surabaya tidak membebani atau mengikat pelajar secara khusus. LAZISMU hanya membantu meringankan beban Pendidikan secara sukarela dan ikhlas. 
Penerima beasiswa tidak dituntut untuk melakukan hal- hal tertentu. Beberapa penerima beasiswa dari LAZISMU ada yang memberikan kontribusi melalui kegiatan pengabdian pada LAZISMU dengan bersedia menjadi relawan LAZISMU baik untuk fokus program filantropis pelajar maupun program lainnya.

\section{Kesimpulan}

Program khusus pendistribusian dana filantropi Islam guna pengembangan pendidikan di daerah Jawa Timur khususnya di kota Surabaya. Program yang dimulai pada tahun 2007 ini menggunakan $25 \%$ dananya guna pengembangan pendidikan.Pengajuan beasiswa Lembaga Amil Zakat Muhammadiyah Surabaya memiliki dua kriteria. Yang pertama adalah beasiswa yang bersifat continue atau berkelanjutan dimana dana Pendidikan tersebut dapat dicairkan setiap 3 bulan sekali. Sedangkan yang kedua adalah dana Pendidikan yang bersifat darurat atau insidentil, dana ini dapat diberikan ketika siswa atau penerima beasiswa mengalami tunggakan dalam pembayaran. Sehingga alokasi dana filantropi Islam untuk program beasiswa pendidikan ini menjadi salah satu peran aktif LAZISMU dalam meningkatkan sumberdaya manusia berdaya saing.

\section{Daftar Pustaka}

[1] A. Fauzia, "Islamic philanthropy in Indonesia: Modernization, islamization, and social justice," Austrian J. South-East Asian Stud., vol. 10, no. 2, pp. 223-236, 2017.

[2] H. Latief, "Islamic philanthropy and the private sector in Indonesia," Indones. J. Islam Muslim Soc., vol. 3, no. 2, pp. 175-201, 2013.

[3] M. Era, C. Economic, and A. Rahmayati, "Filantropi islam: model dan akuntabilitas," Semin. Nas. dan 2nd Call Syariah Pap., no. 1998, pp. 17-29, 2015.

[4] C. N. dan A. Achmadi, Metode Penelitian. Jakarta: Bumi Aksara, 2007.

[5] Muahammad, Metode Penelitian Ekonomi Islam Pendekatan Kuantitatif. Jakarta: Raja Grafindo Persada, 2004.

[6] Iqbal Hasan, Analisis Data Penelitian dengan Statistik. Jakarta: PT Bumi Aksara, 2004.

[7] Q. Uyun, "Zakat, Infaq, Shadaqah, Dan Wakaf Sebagai Konfigurasi Filantropi Islam," Islam. J. Stud. Islam, vol. 2, no. 2, p. 218, 2015.

[8] A. Kasdi, "Filantropi Islam Untuk Pemberdayaan Ekonomi Umat (Model Pemberdayaan ZISWAF di BMT Se-Kabupaten Demak)," IQTISHADIA J. Kaji. Ekon. dan Bisnis Islam, vol. 9, no. 2, p. 227, 2016.

[9] I. H. Tamim, "Peran Filantropi dalam Pengentasan Kemiskinan di dalam Komunitas Lokal," J. Sosiol. Islam, vol. 1, no. 1, pp. 35-58, 2011.

[10] H. Latief, "Islamic Charities and Social Activism," p. 60, 2012.

[11] A. Setiyowati, "Empowering islamic philanthropy: Analysis of entrepreneurial capital assistance program by lazismu surabaya city," Humanit. Soc. Sci. Rev., vol. 7, no. 4, 2019.

[12] Sulkifli, Filantropi Islam Dalam Konteks Pembangunan Sumber Daya Manusia Di Indonesia. Yogyakarta: UIN Sunan Kali Jaga, 2017.

[13] Puskas BAZNAS, INDEKS TRANSPARANSI ORGANISASI PENGELOLA ZAKAT 
(OPZ). 2019.

[14] A. Setiyowati, "DALAM PEMBERDAYAAN EKONOMI UMAT ( Studi Kasus Lazismu Surabaya )," vol. 2, no. 1, 2017. 